\title{
Effect of Biochar and Compost from Chicken, Goat, and Cow Manure on Cultivation of Red Chili (Capsicum annuum $\mathrm{L}$ )
}

\author{
I Kadek Adi Mahendra, Yohanes Parlindungan Situmeang* and Made Suarta \\ Agrotechnology Department, Faculty of Agriculture, Warmadewa University, Denpasar, Bali, Indonesia \\ *E-mail: ypsitumeang63@gmail.com
}

\begin{abstract}
This study aims to determine the effect of compost and biochar fertilizer at a dose of 15 tons ha ${ }^{-1}$ made from livestock manure and its interaction on the growth and yield of red chili plants. This research was conducted in Blahkiuh Village, Abiansemal District, Badung Regency, Bali with an altitude of 400-500 m above sea level. This research was started from February 2020 to July 2020. The design used in this study was a factorial randomized block design (RBD) consisting of 2 factors. The first factor consisted of 4 levels of compost types and the second factor consisted of 2 levels of biochar doses. The interaction between the treatment effect with the type of compost and the type of chicken biochar had no significant effect on all observed variables. The treatment of compost application had a significant to a very significant effect on most of the observed variables, except for the number of leaves, which had no significant effect. The treatment of chicken biochar dosing had a significant to a very significant effect on most variables except for the maximum number of leaves and fresh weight per fruit, which had no significant effect. The results showed that the highest fresh fruit weight was obtained in the type of compost given by chicken livestock, namely $1499.56 \mathrm{~g}$, or an increase of $46.46 \%$ compared to the lowest treatment obtained without compost, namely $1023.85 \mathrm{~g}$. To increase the growth and yield of red chili plants, it is recommended to use compost types of chicken livestock and chicken biochar at a dose of 15 tonnes $\mathrm{ha}^{-1}$, and further research is needed on the provision of biochar and compost types at different locations and types of plants.
\end{abstract}

Keywords: compost, biochar, and chili plants.

\section{Introduction}

Red chili (Capsicum annuum L.) is a seasonal fruit plant, chili is very popular because, with its spicy taste, almost every original Indonesian dish uses chili. Chili is a vegetable commodity that has high economic value and can be grown in various types of soil. Red chilies are a vegetable commodity that people cannot leave behind in their daily lives. Red chilies contain nutrients needed by humans, such as vitamin $\mathrm{A}$, vitamin $\mathrm{C}$, carotene, iron, potassium, calcium, phosphorus, and also contain alkaloids such as capsaicin, flavenoid, and essential oils [1]. Successful cultivation of red chilies promises attractive benefits, but it is not uncommon for red chili farmers to experience significant failures and losses [2].

This condition encourages farmers to use organic fertilizers which have the advantage of containing more complete nutrients than inorganic fertilizers, besides that it is increasingly difficult to get inorganic fertilizers, and also the price is getting more expensive. The use of inorganic fertilizers in the long term causes soil organic matter levels to decrease, soil structure is damaged, and environmental pollution [3]. Therefore, it is hoped that the use of organic fertilizers can act as a provider of plant nutrients and can improve the physical, chemical, and biological properties of soil [4]. One of the organic fertilizers, namely manure, manure is a waste product from domestic animals such as chickens, goats, and cows which can be used to add nutrients, improve the physical and biological properties of the soil. The quality of manure greatly affects the response of plants. Chicken 
manure generally has advantages in nutrient absorption speed, a nutrient composition such as $\mathrm{N}, \mathrm{P}$, $\mathrm{K}$, and $\mathrm{Ca}$ compared to cow and goat manure [5].

Compost is the result of weathering organic matter such as leaves, grass, straw, and so on. Various types of organic matter can be converted into compost with the help of microbes. Compost organic fertilizer can improve soil fertility and nutrient availability for plants. The results of the research by [6] showed that the treatment of 15 tonnes of compost, biochar, and poschar from chicken manure gave significant results in increasing the yield of chilies.

Chicken manure is important in providing macro and micronutrients such as $\mathrm{Zn}, \mathrm{Cu}, \mathrm{Mo}, \mathrm{Co}, \mathrm{Ca}$, $\mathrm{Mg}$, and Si increases the cation exchange capacity (CEC) of soil and can react with metal ions to form complex compounds so that metal ions that poison plants or inhibit the provision of nutrients such as $\mathrm{Al}, \mathrm{Fe}$, and $\mathrm{Mn}$ can be reduced. In chicken manure the nutrient content is $\mathrm{N} 3.21 \%, \mathrm{P} 2 \mathrm{O} 5$ $3.21 \%, \mathrm{~K}_{2} \mathrm{O} 1.57 \%$, Ca 1.57\%, Mg 1.44\%, Mn 250 ppm, and Zn 315 ppm [7].

Apart from the use of organic fertilizers, namely by using composted chicken manure, in Indonesia the potential for using biochar is also quite large, considering that sufficient raw materials are available. Livestock manure which can be used as raw material for biochar, because the source is available and rarely used. The making of charcoal is well known to the people of Indonesia but has not been used as a soil repairer. So far, generally, charcoal production from agricultural waste is intended for export. The use of biochar as a soil amendment material made from agricultural waste that is difficult to decompose is an alternative that can be taken to improve the quality of soil physical properties so that crop production can be increased [8]. Biochar is biological charcoal from incomplete combustion (pyrolysis), organic matter from agricultural products that can improve soil quality and can be used as an alternative for soil management [9].

Another benefit of biochar is that it can store carbon stably for thousands of years by immersing it in the soil. Various studies that have been conducted have shown that biochar application can save fertilizer use and increase soil and plant productivity. Biochar can improve soil quality by converting agricultural waste into soil enhancers that store carbon and make the soil more fertile, applying biochar to agricultural land can increase P, K content, microbial activity, and soil quality and can help reduce nitrogen leaching into water soil and reduce fertilizer costs [10].

The use of biochar can retain nutrients and water and increase nutrient availability in the soil. Research [11] and [12], that the best response to growth and yield of maize was obtained in the 10 ton $\mathrm{ha}^{-1}$ biochar treatment. Meanwhile, the yield of pakchoy vegetables on biochar administration of 10 tonnes ha ${ }^{-1}$ can also increase significantly [13]. The research [14], showed that the treatment of compost dosage of 30 ton per ha and biochar made from coconut shells gave the highest fresh weight of chilies. The purpose of this study was to determine the effect of compost type and dosage of biochar made from livestock manure and its interaction on the growth and yield of red chilies.

\section{Material and Methods}

This research was conducted in Blahkiuh Village, Abiansemal District, Badung Regency. With a height of 400 meters above sea level. This research took place from February 2020 to July 2020. The material used is the variety of red chili seeds (Smart F1), which is produced by Tunas Agro Seeds, compost for chicken, cow, and goat. While the materials used in the process of making biochar are chicken manure and firewood. The tools used in this study: hoe, meter, sprayer, and scales.

This study used a factorial randomized block design (RBD) with 2 treatment factors. The first factor is the type of livestock manure compost which consists of 4 levels, namely: Without Compost (K0), Cow manure compost (Ks), Chicken manure compost (Ka), Goat manure compost (Kk). While 
the second factor is the dose of chicken manure biochar which consists of 2 levels, namely: 0 tons $\mathrm{ha}^{-1}$ (B0) and 15 tons ha- ${ }^{-1}(\mathrm{Ba})$. From these treatments, 8 treatment combinations were obtained. This treatment combination was then repeated 3 times to obtain 24 experimental plots.

The research data were analyzed by using analysis of diversity to determine the effect of treatment on the measured variables. Meanwhile, to determine the real difference between treatments using the LSD test with a level of 5\%. To determine the closeness of the relationship between the observed variables in the compost treatment, a correlation analysis was performed.

\section{Results and Discussion}

\subsection{Results}

The significance of the effect of the type of compost (K) and the dose of biochar (B) on the variables observed during the study is presented in (Table 1). Table 1 shows that the interaction between compost type treatment and biochar dose of 15 ton $\mathrm{ha}^{-1}(\mathrm{KxB})$ had no significant effect $(\mathrm{P} \geq 0.05)$ on all observed variables. The treatment of compost type had a significant to a very significant effect on most of the observed variables, for which a very significant effect $(\mathrm{P}<0.01)$ was seen in the variables of maximum plant height, stem diameter, and fruit fresh weight, for which had a significant effect $(\mathrm{P}$ $<0.05)$ it can be seen in the variable number of fruits, fresh weight per fruit and oven-dry weight of fruit, while for the variable which has no significant effect $(\mathrm{P} \geq 0.05)$ is found in the variable maximum number of leaves. In the treatment, the dose of biochar had a significant to a very significant effect on some of the observed variables, for variables that had a very significant effect $(\mathrm{P}<0.01)$ were found on the maximum plant height, stem diameter, number of fruit, fresh weight of fruit and fresh weight per fruit, for variables Significant effect $(\mathrm{P}<0.05)$ was found on the oven-dry weight of fruit, while variables with no significant effect $(\mathrm{P} \geq 0.05)$ were found on the maximum number of leaves and fresh weight per fruit.

Table 1

The significance of the effect of the type of compost (K) and the dose of biochar (B) and its interaction $(\mathrm{KxB})$ on the growth and yield variables of red chilies.

\begin{tabular}{clccc}
\hline \multirow{2}{*}{ No } & \multicolumn{1}{c}{ Variable } & Types of Compost & $\begin{array}{c}\text { Biochar dosage } \\
(\mathrm{K})\end{array}$ & $\begin{array}{c}\text { Interaction } \\
\text { KxB }\end{array}$ \\
\hline 1. & Maximum plant height $(\mathrm{cm})$ & $* *$ & $\mathrm{~ns}$ & $\mathrm{~ns}$ \\
2. & Maximum number of leaves (sheet) & $\mathrm{ns}$ & $* *$ & $\mathrm{~ns}$ \\
3. & Stem diameter $(\mathrm{mm})$ & $* *$ & $* *$ & $\mathrm{~ns}$ \\
4. & Number of fruit (fruit) & $*$ & $* *$ & $\mathrm{~ns}$ \\
5. & Fruit fresh weight $(\mathrm{g})$ & $* *$ & $\mathrm{~ns}$ & $\mathrm{~ns}$ \\
6. & Fresh weight per fruit $(\mathrm{g})$ & $*$ & $*$ & $\mathrm{~ns}$ \\
7. & Fruit oven dry weight $(\mathrm{g})$ & $*$ & $\mathrm{~ns}$ \\
\hline
\end{tabular}

Note: $*$ significant $(\mathrm{P}<0.05),{ }^{*}=$ very significant $(\mathrm{P}<0.01), \mathrm{ns}=$ non significant $(\mathrm{P} \geq 0.05)$.

The results showed that the highest fresh fruit weight was obtained in the type of chicken compost (Ka), which was $1499.56 \mathrm{~g}$ or an increase of $46.46 \%$ compared to the lowest treatment obtained without compost (Ko), namely $1023.85 \mathrm{~g}$ (Table 2). While the treatment of chicken biochar dose of 15 ton ha-1 gave the highest fresh weight of fruit $1395.37 \mathrm{~g}$ which increased $23.69 \%$ compared to without biochar $1128.10 \mathrm{~g}$ (Table 2). 
Table 2

The mean of the observed variables was due to the influence of the type of compost $(\mathrm{K})$ and the dose of biochar (B).

\begin{tabular}{|c|c|c|c|c|c|c|c|}
\hline Treatment & $\begin{array}{l}\text { Plant } \\
\text { height } \\
(\mathrm{cm})\end{array}$ & $\begin{array}{c}\text { Number of } \\
\text { leaves } \\
\text { (sheet) }\end{array}$ & $\begin{array}{c}\text { Stem } \\
\text { diameter } \\
(\mathrm{mm})\end{array}$ & $\begin{array}{c}\text { Number } \\
\text { of fruit } \\
\text { (fruit) }\end{array}$ & $\begin{array}{c}\text { Fruit } \\
\text { fresh weight } \\
(\mathrm{g})\end{array}$ & $\begin{array}{c}\text { Fresh weight } \\
\text { per fruit } \\
(\mathrm{g})\end{array}$ & $\begin{array}{l}\text { Fruit oven } \\
\text { dry weight } \\
\text { (g) }\end{array}$ \\
\hline \multicolumn{8}{|l|}{ Compost $(\mathrm{K})$} \\
\hline Without compost (Ko) & $84.19 \mathrm{~b}$ & $94.42 \mathrm{~b}$ & $11.63 \mathrm{c}$ & $75.58 \mathrm{~b}$ & $1023.85 \mathrm{~b}$ & $14.10 \mathrm{~b}$ & $185.38 \mathrm{~b}$ \\
\hline Cow compost (Ks) & $92.99 \mathrm{a}$ & $107.42 \mathrm{ab}$ & $12.30 \mathrm{bc}$ & 89.88 a & $1221.09 \mathrm{a}$ & $14.43 \mathrm{~b}$ & $221.72 \mathrm{ab}$ \\
\hline Chicken compost (Ka) & $94.83 \mathrm{a}$ & $120.67 \mathrm{a}$ & $14.28 \mathrm{a}$ & $98.50 \mathrm{a}$ & $1499.56 \mathrm{a}$ & $15.87 \mathrm{a}$ & $262.02 \mathrm{a}$ \\
\hline Goat compost $(\mathrm{Kk})$ & $91.88 \mathrm{a}$ & $108.92 \mathrm{ab}$ & $12.99 \mathrm{~b}$ & $90.46 \mathrm{a}$ & $1302.43 \mathrm{ab}$ & $15.04 \mathrm{a}$ & $238.17 \mathrm{~b}$ \\
\hline BNT 5\% & 4.54 & 22.64 & 0.95 & 13.05 & 224.11 & 1.02 & 47.22 \\
\hline \multicolumn{8}{|l|}{$\begin{array}{l}\text { Chicken Biochar } \\
\text { Dosage (B) }\end{array}$} \\
\hline 0 ton $\mathrm{ha}^{-1}(\mathrm{~B} 0)$ & $86.33 \mathrm{~b}$ & $103.42 \mathrm{a}$ & $13.23 b$ & $81.44 \mathrm{~b}$ & $1128.10 \mathrm{~b}$ & $14.57 \mathrm{a}$ & $205.15 \mathrm{~b}$ \\
\hline 15 ton $\mathrm{ha}^{-1}(\mathrm{Ba})$ & $95.62 \mathrm{a}$ & $112.31 \mathrm{a}$ & $13.36 \mathrm{a}$ & $95.77 \mathrm{a}$ & $1395.37 \mathrm{a}$ & $15.15 \mathrm{a}$ & $248.51 \mathrm{a}$ \\
\hline BNT 5\% & 3.21 & - & 0.67 & 9.23 & 158.47 & - & 33.38 \\
\hline
\end{tabular}

Note: The mean value followed by the same letter at the same treatment and row, means that it is not significantly different at the 5\% LSD test level.

The high yield of fresh fruit weight was supported by a positive and significant correlation as shown in the variable maximum plant height $(\mathrm{r}=0.90 * *)$, maximum number of leaves $(\mathrm{r}=0.99 * *)$, and stem diameter $(\mathrm{r}=0.98 . * *)$, number of fruit $(\mathrm{r}=0.97 * *)$, fresh weight per fruit $(\mathrm{r}=0.97 * *)$, and oven dry weight of fruit $(\mathrm{r}=0.99 * *)$.

Table 3

The correlation coefficient between variables $(r)$ is due to the influence of the type of compost

\begin{tabular}{|c|c|c|c|c|c|c|c|}
\hline & $\mathrm{X} 1$ & $\mathrm{X} 2$ & X3 & $\mathrm{X} 4$ & X5 & X6 & X7 \\
\hline $\mathrm{X} 1$ & 1 & & & & & & \\
\hline $\mathrm{X} 2$ & $0.93 * *$ & 1 & & & & & \\
\hline X3 & $0.81 * *$ & $0.96 * *$ & 1 & & & & \\
\hline $\mathrm{X} 4$ & $0.98 * *$ & $0.99 * *$ & $0.91 * *$ & 1 & & & \\
\hline X5 & $0.90 * *$ & $0.99 * *$ & $0.98^{* * *}$ & $0.97 * *$ & 1 & & \\
\hline X6 & $0.76^{* * *}$ & $0.94 * *$ & $1.00 * *$ & $0.88 * *$ & $0.97 * *$ & 1 & \\
\hline $\mathrm{X} 7$ & $0.92 * *$ & $0.99 * *$ & $0.96 * *$ & $0.98 * *$ & $0.99 * *$ & $0.95 * *$ & 1 \\
\hline
\end{tabular}

$\mathrm{r}(0.05 ; 10 ; 1)=0.576 \quad \mathrm{r}(0.01 ; 10 ; 1)=0.708$

Note:

$\mathrm{X} 1=$ Maximum plant height

$\mathrm{X} 2$ = Maximum number of leaves

$\mathrm{X} 3$ = Stem diameter

$\mathrm{X} 4=$ Number of fruit

$\mathrm{X} 5$ = Fruit fresh weight

$\mathrm{X} 6=$ Fresh weight per fruit

$\mathrm{X} 7$ = Fruit oven-dry weight

$*$ significant $(\mathrm{P}<0,01)$

$* *=$ very significant $(\mathrm{P}<0,05)$

$\mathrm{tn}=$ non significant $(\mathrm{P} \geq 0,05)$ 


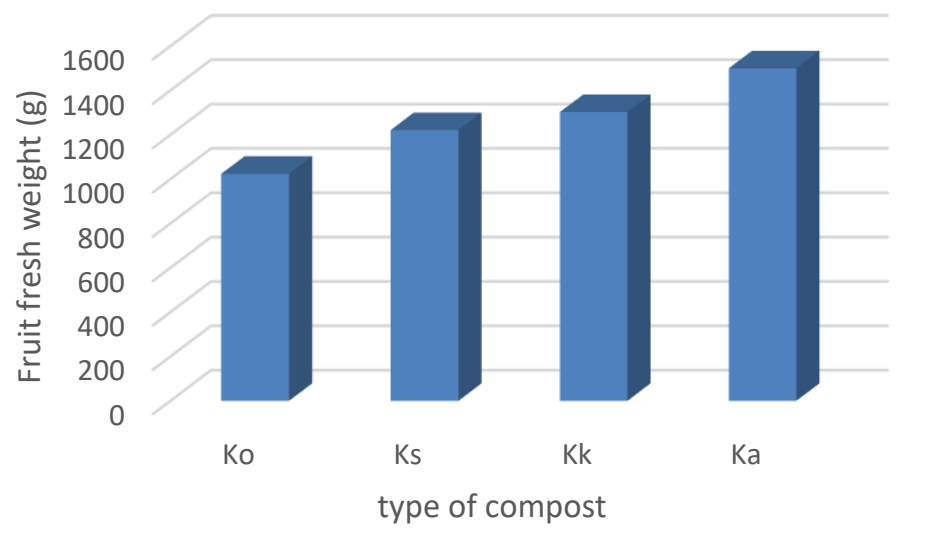

Figure 1. Histogram of the relationship between various types of compost treatment and fruit fresh weight.

The high yield of fresh fruit weight in chicken compost $(\mathrm{Ka})$ is due to the provision of chicken compost which can provide complete nutrients needed by plants, such as macronutrients $\mathrm{N}, \mathrm{P}, \mathrm{K}$, and some micronutrients. As for other variables that affect the high yield of fresh fruit weight, namely the maximum plant height of all types of compost given, the highest plant height was obtained in the treatment of chicken compost, this is due to the presence of $\mathrm{P}$ elements that are more widely available in chicken compost, $\mathrm{P}$ elements are needed. plants to strengthen the roots, lack of $\mathrm{P}$ elements plant roots will be disrupted, besides that $\mathrm{P}$ also plays a role in the process of energy transfer, photosynthesis, metabolism, and respiration.

Besides, the number of leaves also affects the fresh weight of the fruit from the results of the research, the highest number of leaves obtained in the compost treatment is supported by the presence of macro and microelements present in the compost. The elements that play a role are magnesium and potassium where these two elements bond together so that the leaves on the red chili plant do not fall off. The number of fruit also affects the high yield of fresh fruit weight, the highest number of fruit is also found in the provision of chicken compost, this is influenced by the element of Phosphorus $(\mathrm{P})$ which is owned by the compost. The element Phosphorus is related to the biochemical metabolism which stores energy and then transfers it to living cells. The element of phosphorus serves to stimulate root growth, flowers, and fruit ripening.

This is in line with [15] which states that giving chicken compost can contribute complete nutrients needed by plants, such as N, P, K, and several micronutrients in the form of Fe, Zn, and Mo. [16] added that compost has many advantages including a complete content of macro and micronutrients. The number of fruit also affects the high yield of fresh fruit weight, the highest number of fruit is also found in the provision of chicken compost, this is influenced by the element of Phosphorus $(\mathrm{P})$ which is owned by the compost. The element Phosphorus is related to the biochemical metabolism which stores energy and then transfers it to living cells. The element of phosphorus serves to stimulate root growth, flowers, and fruit ripening.

The chicken manure compost given contains EM4 which can ferment organic material to produce compounds that can be absorbed directly by plant roots. According to [17], bokashi derived from chicken manure contains several nutrients and organic materials that can improve soil physical, chemical, and biological properties. The availability of nutrients in the soil, soil structure, and good soil air conditioning greatly affect root growth and development and the ability of plant roots to absorb nutrients. With a sufficiently high $\mathrm{pH}$ of chicken manure compost that is applied to the soil, it can help in increasing the availability of phosphorus in the soil which generally becomes a barrier in acid soils while suppressing the toxicity of Al. 
The potassium can strengthen plant tissues and organs so that they do not fall off easily, and increase the translocation of photosynthetic products into the phloem [18]. According to [19], lack of nutrients in the soil can result in low productivity in red chilies. If nutrients in the soil are not available, plant growth will be stunted and production will decline.

The application of biochar can also increase soil $\mathrm{pH}$, increase soil aggregate so that it can increase fungal hyphae, increase soil water content, increase the ability of the soil to provide $\mathrm{Ca}, \mathrm{Mg}, \mathrm{P}$ and $\mathrm{K}$, increase soil microbial respiration, increase soil microbial biomass, increase cation exchange capacity, increase crop yields (20-120\%), and improve the quality of plant products [9].



Figure 2. Histogram of the relationship between biochar treatment and fruit fresh weight.

The high yield of fresh fruit weight obtained from the treatment of biochar with a dose of 15 tonnes ha ${ }^{-1}$ is because Biochar is a soil repairer that can retain nutrients and water in the soil. Nutrient retention affects the growth of nutrients for plants, due to the nature of biochar which can improve soil aeration and drainage due to better soil porosity, decreased soil compaction, nutrient retention and soil water, and increased soil CEC. In line with the results of research by Situmeang et al. 2019 [9] that the application of compost and biochar from chicken manure as much as 15 tons per ha gives the best results compared to compost and biochar from cow and goat manure.

\section{Conclusion}

There was no interaction between compost type and biochar dose in all observed variables. Treatment of compost type had a significant to a very significant effect on most of the observed variables, except for the maximum number of leaves, which had no significant effect. While the treatment of biochar dose had a significant to a very significant effect on some of the observed variables, except for the maximum number of leaves and fresh weight per fruit, which had no significant effect. The treatment of chicken compost gave the highest yield of fresh fruit weight, namely $1499.56 \mathrm{~g}$ which increased $46.46 \%$ compared to without compost of $1023.85 \mathrm{~g}$. Treatment of chicken biochar with a dose of 15 tonnes $^{-1} \mathrm{a}^{-1}$ gave the highest fruit fresh weight $1395.37 \mathrm{~g}$ which increased $23.69 \%$ compared to without biochar $1128.10 \mathrm{~g}$. 


\section{References}

[1] Devi, R. N. (2010). Budidaya Tanaman Cabai Merah. Skripsi. Universitas Sebelas Maret. Surakarta.

[2] Sumarni, N. dan Muharam, A. (2005). Budidaya Tanaman Cabai Merah. Seri Panduan Teknis PPT Cabai Merah No. 2. Balai Penelitian Tanaman Sayuran.Gani, A., (2009). Biochar Penyelamat Lingkungan. Warta Penelitian dan Pengembangan Pertanian. 31(6)

[3] Simanjuntak, A., Lahay, R.R., Purba, E. (2013). Respon Pertumbuhan Dan Produksi Bawang Merah (Allium Ascalonicum L.) Terhadap Pemberian Pupuk NPK Dan Kompos Kulit Buah Kopi. Agroekoteknologi 1(3)

[4] Sunarjono, H.H. (2004). Bertanam 30 Jenis Sayuran. Penebar Swadaya. Jakarta.

[5] Widowati. L. R., Widati, U. S., Jaenudin, W. Hrtatik. (2004). Pengaruh Kompos Pupuk Organik yang Diperkaya dengan Bahan Mineral dan Pupuk Hayati terhadap Sifat-sifat Tanah, Serapan Hara dan Produksi Sayuran Organik. Laporan Proyek Penelitian Program Pengembangan Agribisnis. Balai Penelitian Tanah.

[6] Situmeang, Y.P., Sudita I. D.N., and Suarta, M., (2019). Manure Utilization from Cows, Goats, and Chickens as Compost, Biochar, and Poschar in Increasing the Red Chili Yield. International Journal on Advanced Science, Engineering and Information Technology, 9(6), 2088-2095

[7] Wiryanta. W dan Bernardinus T. (2002). Bertanam Cabai Pada Musim Hujan. Agromedia Pustaka. Jakarta.

[8] Lehmann, J. (2007). A handful of carbon. Nature, 447: 143-144

[9] Gani, A., (2009). Biochar Penyelamat Lingkungan. Warta Penelitian dan Pengembangan Pertanian. Vol. 31, No. 6.

[10] Situmeang Y P, Adnyana I M, Subadiyasa I N N, and Merit I N (2018) Effectiveness of Bamboo Biochar Combined with Compost and NPK Fertilizer to Improved Soil Quality and Corn Yield. International Journal on Advanced Science, Engineering and Information Technology, 8(5), 2241-2248

[11] Situmeang, Y. P., Adnyana, I. M., Subadiyasa, I. N. N., \& Menit, I. N. (2015). Effect of Dose Biochar Bamboo, Compost, and Phonska on Growth of Maize (Zea Mays L.) In Dryland. International Journal on Advanced Science, Engineering and Information Technology, 5(6), 433-439.

[12] Lelu, P.K., Situmeang, Y.P., Suarta, M. (2018). Aplikasi Biochar dan Kompos Terhadap Peningkatan Hasil Tanaman Jagung (Zea Mays L.). Gema Agro, 23(1), 24-32.

[13] Situmeang, Y.P., Sudewa, K.A., \& Holo, P.P. (2017). Utilization Biochar of Bamboo and Compost in Improving Yield of Pakchoy Plant. Journal of Biological and Chemical Research, 34(2): 713-722.

[14] Amaral, H. D. D. R., Situmeang, Y. P., \& Suarta, M. (2019, December). The effects of compost and biochar on the growth and yield of red chili plants. In Journal of Physics: Conference Series (Vol. 1402, No. 3, p. 033057). IOP Publishing.

[15] Harsono. (2009). Pupuk Organik Kotoran Ayam. http://thlbanyumas.blogspot.com/ kandungan-pupukpadakotoranhewan.html

[16] Stofella DJ, Khan B.A. (2001). Compost Utilization in Horticultural Croping System. Lewis Publishers. Washington D.C.

[17] Subhan F, Hamzah, Wahab A. (2008). Aplikasi bokashi kotoran ayam pada tanaman melon. Jurnal Agrisistem 4(1):1-10.

[18] Gardner FP, Pearce RB, Mitchell RL. (1991). Fisiologi Tanaman Budidaya. UI Press. Jakarta.

[19] Ibrahim. (2012.) http://petunjukbudidaya.blogspot.com/2012/12/ defisiensiunsur-hara.html 